\title{
Geothermal Energy in Western Europe
}

by

\section{J. Lavigne}

Although industrial application of geothermal energy dates only from the beginning of the present century, use of energy from this source has greatly increased in recent years, both at the high energy level - in supplying steam to power stations, and at the low energy level - in supplying warm water for central heating and argicultural use.

Steam is generated in those regions of Europe with current or recent magmatic or volcanic activity. Sources of warm water are much less narrowly localized. Of greatest economic interest, however, are the deep sedimentary basins, where waters in aquifers are heated to high temperatures and can be used directly for heating of dwellings.

\section{Volcanic regions}

Regions of active volcanism are found in southern Europe, chiefly in Greece and Italy, as well as in Iceland and the Azores.

Italy today has an installed capacity of more than $420 \mathrm{MW}$, representing an annual output of the order of $3000 \mathrm{GWh}$. The source-aquifers lie in the "borax-bearing region" of Tuscany (the fields of Larderello, Castelnuovo, Serrazzano, Lago, Travale), with an installed capacity of $400 \mathrm{MW}$, while in the Monte Amiata region the installed capacity is $20 \mathrm{MW}$. Exploration is being pursued in the whole of the pre-Appennine zone from Pisa in the north to Naples in the south, which includes the regions of Travale, Monte Volsini, Monte Cimini, Monte Sabatini, Naples, Volterra.

In Greece, a potential source has been discovered on the island of Melos and evaluation is continuing. In Iceland small power stations (7 MW) are working in the Reykjavik area. Exploration is active in France (particularly in the Mont Dore area) and in the Azores.

\section{Sedimentary basins}

Major basins recognized in the past as being potentially interesting to petroleum exploration are currently being explored again in several countries for sources of sufficiently warm water stored in deep-seated aquifers. In France there are four working installations in the Paris Basin (Melun l'Almont, Melun les Courtilleraies, Villenneuve-la-Garenne and Creil), and three more in the Aquitaine basin (Blagnac, Mont-de-Marsan, Dax). Other plants are under construction in both regions and also in the Alsace trench. Current production supplies heat to some 15000 dwellings.
While similar installations using hot water have long been used in Hungary and Iceland, potential sources are being evaluated in most of the sedimentary basins of Spain, Italy, Yugoslavia, Switzerland, Germany, the United Kingdom, Nether lands, Belgium, and Denmark.

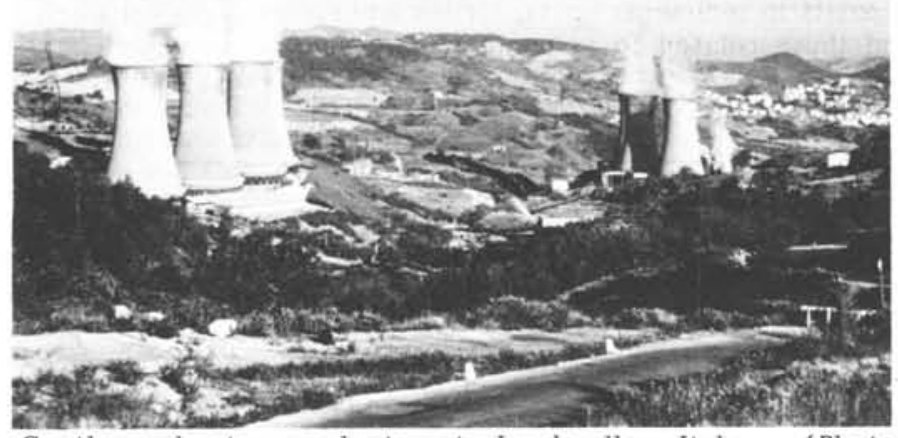

Geothermal steam plants at Larderello, Italy.

(Photo courtesy A.M. Jessop)

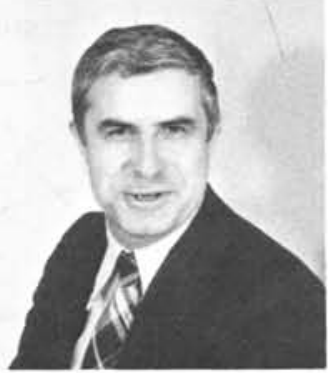

ABOUT THE AUTHOR: Jacques Lavigne has spent much of his professional career in petroleum research, having been chief geologist in charge of prospecting in the European part of the North Sea for the company Régie Autonome des Petroles. He now heads the program planning section in the BRGM, France. 